\title{
Correction to: Evaluation of host susceptibility, preference and offspring performance of Zeugodacus cucurbitae (Coquillett) (Diptera: Tephritidae) on different hosts
}

\author{
Muzammil Farooq ${ }^{1} \cdot$ Sangita Baig ${ }^{1,2} \cdot$ Sabyan Faris Honey $^{1} \cdot$ Babar Ehsan Bajwa $^{1} \cdot$ Fazlullah $^{1} \cdot$ Iqbal Hussain Shah $^{2}$
}

Published online: 20 May 2020

(C) The Author(s) 2020

\section{Correction to: International Journal of Tropical Insect Science (2020) 40:93-99 https://doi.org/10.1007/s42690-019-00056-Z}

The above mentioned article, was originally published Online First without Open Access. After publication in volume 40, issue 1, page 93-99 the author decided to opt for Open Choice and to make the article an Open Access publication. Therefore, the copyright of the article has been changed to (C) The Author(s) 2020 and the article is forthwith distributed under the terms of the Creative Commons Attribution 4.0 International License (http://creativecommons.org/licenses/ by/4.0/), which permits use, duplication, adaptation, distribution and reproduction in any medium or format, as long as you give appropriate credit to the original author(s) and the source, provide a link to the Creative Commons license, and indicate if changes were made.

In addition, the Acknowledgment section as well as the Funding section were modified in the original publication to read as follows:

Acknowledgements We gratefully acknowledge Mr. Riaz Mahmood, CABI's Biological Control Specialist for providing technical inputs in this study. Acknowledgement is also made to Integrated Pest Management Unit (IPM), Department of Agriculture Extension GilgitBaltistan for providing facilitation during this research.

Funding information This study was funded by United States Agency for International Development (USAID) through United States Department

The online version of the original article can be found at https://doi.org/ 10.1007/s42690-019-00056-Z

Muzammil Farooq

M.Farooq@cabi.org

1 Centre for Agriculture and Bioscience International (CABI), Regional Bioscience Centre (Central \& West Asia), 1-A oppositeData Gunj Bakhsh Road, Rawalpindi, Pakistan

2 Department of Agriculture Gilgit Baltistan, Gilgit, Pakistan of Agriculture (USDA) under the CABI's project "Phytosanitary Risk Management Program in Pakistan" (PRMP). CABI is an international intergovernmental organisation, and we gratefully acknowledge the core financial support from our member countries (and lead agencies) including the United Kingdom (Department for International Development), China (Chinese Ministry of Agriculture), Australia (Australian Centre for International Agricultural Research), Canada (Agriculture and AgriFood Canada), Netherlands (Directorate-General for International Cooperation), and Switzerland (Swiss Agency for Development and Cooperation). See http://www.cabi.org/about-cabi/who-we-work-with/ key-donors/ for full details.

Open Access This article is licensed under a Creative Commons Attribution 4.0 International License, which permits use, sharing, adaptation, distribution and reproduction in any medium or format, as long as you give appropriate credit to the original author(s) and the source, provide a link to the Creative Commons licence, and indicate if changes were made. The images or other third party material in this article are included in the article's Creative Commons licence, unless indicated otherwise in a credit line to the material. If material is not included in the article's Creative Commons licence and your intended use is not permitted by statutory regulation or exceeds the permitted use, you will need to obtain permission directly from the copyright holder. To view a copy of this licence, visit http://creativecommons.org/licenses/by/4.0/.

Publisher's note Springer Nature remains neutral with regard to jurisdictional claims in published maps and institutional affiliations. 